\title{
Phospholipase D inhibitors reduce human prostate cancer cell proliferation and colony formation
}

\author{
Amanda R Noble*, ${ }^{*}$, Norman J Maitland ${ }^{1}$, Daniel M Berney ${ }^{2}$ and Martin G Rumsby ${ }^{1}$ \\ ${ }^{1}$ Department of Biology, Cancer Research Unit, University of York, York YO10 5DD, UK and ${ }^{2}$ Department of Molecular Oncology, \\ Barts Cancer Institute, Queen Mary University of London, London EC1M 6BO, UK
}

Background: Phospholipases D1 and D2 (PLD1/2) hydrolyse cell membrane glycerophospholipids to generate phosphatidic acid, a signalling lipid, which regulates cell growth and cancer progression through effects on mTOR and PKB/Akt. PLD expression and/ or activity is raised in breast, colorectal, gastric, kidney and thyroid carcinomas but its role in prostate cancer (PCa), the major cancer of men in the western world, is unclear.

Methods: PLD1 protein expression in cultured PNT2C2, PNT1A, P4E6, LNCaP, PC3, PC3M, VCaP, 22RV1 cell lines and patientderived PCa cells was analysed by western blotting. PLD1 protein localisation in normal, benign prostatic hyperplasia (BPH), and castrate-resistant prostate cancer (CRPC) tissue sections and in a PCa tissue microarray (TMA) was examined by immunohistochemistry. PLD activity in PCa tissue was assayed using an Amplex Red method. The effect of PLD inhibitors on PCa cell viability was measured using MTS and colony forming assays.

Results: PLD1 protein expression was low in the luminal prostate cell lines (LNCaP, VCaP, 22RV1) compared with basal lines (PC3 and PC3M). PLD1 protein expression was elevated in BPH biopsy tissue relative to normal and PCa samples. In normal and BPH tissue, PLD1 was predominantly detected in basal cells as well in some stromal cells, rather than in luminal cells. In PCa tissue, luminal cells expressed PLD1. In a PCa TMA, the mean peroxidase intensity per DAB-stained Gleason 6 and 7 tissue section was significantly higher than in sections graded Gleason 9. In CRPC tissue, PLD1 was expressed prominently in the stromal compartment, in luminal cells in occasional glands and in an expanding population of cells that co-expressed chromogranin A and neurone-specific enolase. Levels of PLD activity in normal and PCa tissue samples were similar. A specific PLD1 inhibitor markedly reduced the survival of both prostate cell lines and patient-derived PCa cells compared with two dual PLD1/PLD2 inhibitors. Short-term exposure of PCa cells to the same specific PLD1 inhibitor significantly reduced colony formation.

Conclusions: A new specific inhibitor of PLD1, which is well tolerated in mice, reduces PCa cell survival and thus has potential as a novel therapeutic agent to reduce prostate cancer progression. Increased PLD1 expression may contribute to the hyperplasia characteristic of $\mathrm{BPH}$ and in the progression of castrate-resistant PCa, where an expanding population of neuroendocrine-like cells express PLD1.

Phospholipase D (PLD) hydrolyses major membrane glycerophospholipids to phosphatidic acid ( $\mathrm{PtdOH})$, an intermediate in complex lipid synthesis. PtdOH is also a key signalling lipid that activates proteins at membrane surfaces (Kooijman et al, 2003) and regulates cell survival (Foster, 2009). Due to its inverted cone shape, PtdOH can also alter membrane curvature, facilitating the vesicle formation (Yang et al, 2008) needed to increase tumour cell proliferation.

*Correspondence: Dr AR Noble; E-mail: amanda.noble@york.ac.uk

Received 21 July 2017; revised 17 September 2017; accepted 2 October 2017; published online 14 November 2017

(C) 2018 Cancer Research UK. All rights reserved 0007 - 0920/18 
The PtdOH generated by PLD activity can regulate cell survival and motility through mTOR, a master regulator of cancer cell survival and growth, which controls protein synthesis, migration, invasion and metastasis (Foster, 2009). PtdOH formation also leads to inhibition of protein phosphatase 1 and upregulation of the ERK, $\mathrm{PKB} / \mathrm{Akt}, \mathrm{NF} \kappa \mathrm{B}$ and Wnt signalling pathways, further promoting both cancer cell survival and metastasis (Foster, 2009; Winter et al, 2010; Kang et al, 2011; Yoon et al, 2011). Abnormal activation of $\mathrm{Wnt} / \beta$-catenin signalling and hyperactivation of transcriptional target genes has been linked to prostate cancer (PCa) and especially metastasis to bone in castration-resistant disease (Hall and Keller, 2006; Yokoyama et al, 2014).

PLD1 and PLD2 are the two main isoforms of PLD in human cells (Foster and $\mathrm{Xu}, 2003$ ). PLD1 has a diffuse cytoplasmic localisation (Freyberg et al, 2001) and is activated by protein kinase C (PKC) (Kim et al, 2000), casein kinase-II (Ahn et al, 2006) and by the small GTPases ARF and RHO (Foster, 2009). In contrast, PLD2 is located at the plasma membrane and is activated by both $\mathrm{PKC}$ and by receptor (EGFR, PDGFR) and non-receptor (Src, JAK3) tyrosine kinases (Henkels et al, 2010). PLD2 has a higher basal activity than PLD1 and acts as both a phospholipase and as a guanine nucleotide exchange factor (Kang et al, 2014). Total PLD activity is increased in gastric cancer (Uchida et al, 1999) and breast cancer where levels correlate with disease grade (Uchida et al, 1997). PLD1 is overexpressed in human breast cancer tissue (Noh et al, 2000), while PLD2 expression is increased in renal (Zhao et al, 2000) and thyroid carcinomas (Kim et al, 2008). Expression of PLD2 is increased in colorectal cancer where it correlates with tumour size and prognosis (Saito et al, 2007). In a human breast carcinoma xenograft model, PLD2 drives cell invasion, tumour growth and metastasis (Henkels et al, 2013). Inhibition of either PLD1 or PLD2 also makes breast cancer cells more susceptible to radiotherapy (Cheol Son et al, 2013). New isoform-specific PLD inhibitors can reduce proliferation of breast cancer cells in mice and are well tolerated (Henkels et al, 2013). If similar overexpression of PLD is present, these new inhibitors have potential as alternative therapeutic agents to hormone-based and other current therapies used to treat PCa.

\section{MATERIALS AND METHODS}

Prostate epithelial cell lines. The prostate cell lines used with their growth media requirement, diagnosis and origin are listed in Table 1.

Patient-derived prostate epithelial and stromal cells. Primary prostate epithelial and stromal cells were cultured from human prostate tissues (Collins et al, 2001; Frame et al, 2016), which were obtained with patient consent and full ethical approval (LREC:07/ H1304/121) from radical prostatectomies and transurethral resections of the prostate (TURPS). Histopathology information was provided for pre- and post-operative samples as a Gleason grade, or verifying morphology as normal. Epithelial cells were grown on collagen 1-coated $10 \mathrm{~cm}$ dishes in KSFM with supplements of $1 \%$ L-glutamine, bovine pituitary extract and epidermal growth factor at $37{ }^{\circ} \mathrm{C}$ with $5 \% \mathrm{CO}_{2}$. For the first passage, cells were co-cultured with irradiated (60 Gy) mouse embryonic fibroblast (STO) cells. Subsequent passages were free of STOs and all cultures were used at the lowest practical passage number after establishment in culture (p2-p5). Stromal cells were cultured in RPMI 1640 with $10 \%$ FCS and $1 \%$ glutamine.

Western blotting. Epithelial cell lysates were prepared using Cytobuster Protein Extraction Reagent (71009, EMD Millipore, Watford, UK) with protease inhibitors (cOmplete, EDTA-free Protease Inhibitor Cocktail Tablets, Roche, Burgess Hill, UK). Stromal cell lysates were prepared in a $1 \%$ TX-100 lysis buffer containing protease inhibitors. SDS-PAGE and western blotting were as described previously (Rumsby et al, 2011). Primary antibodies were an anti-PLD1 rabbit polyclonal (sc25512, Santa Cruz, Insight Biotechnology, Wembley, UK, 1:750), and a rabbit anti-GAPDH polyclonal (Abcam, Cambridge, UK, ab9485, $1: 20000)$. The secondary antibody was HRP-linked anti-rabbit IgG (7074S, Cell Signalling, New England Biolabs Ltd, UK, 1:6000). A kaleidoscope protein ladder (Bio-Rad, Watford, UK, Cat No 1610375) was used throughout.

PLD activity. PLD activity was measured with an Amplex Red PLD kit (A12219, Invitrogen, Fisher Scientific Ltd, Loughborough, UK) according to the manufacturer's instructions. Prostate tissue was chopped in the supplied buffer containing $1 \%$ peroxide-free Triton X-100 and protease inhibitors. The chopped tissue in buffer was put through three freeze/thaw cycles at $-80^{\circ} \mathrm{C}$, homogenised and centrifuged at $1000 \mathrm{~g}$ and $4{ }^{\circ} \mathrm{C}$ for $5 \mathrm{~min}$ to remove cell debris. The supernatant was used for analysis. PLD activity was assayed with $50 \mu \mathrm{g}$ supernatant protein (measured by a bicinchoninic acid [BCA] method) in triplicate, where sufficient tissue was available. PLD from Streptomyces chromofucus (P0065, Sigma Aldrich Company Ltd, Poole, UK) was used to produce a new standard curve for every set of measurements.

PLD inhibition and cell viability. The effects of PLD inhibition on the viability of prostate epithelial cell lines and patient-derived PCa cells was measured using an MTS ([3-(4,5-dimethylthiazol-2yl)-5-(3-carboxymethoxyphenyl)-2-(4-sulfophenyl)-2H-tetrazolium) assay (Promega, Southhampton, UK). Wells of a 96-well plate were filled with $100 \mu \mathrm{l}$ of appropriate medium or medium containing DMSO vehicle or different PLD inhibitors over a 1$25 \mu \mathrm{M}$ concentration range. A total of $1 \times 10^{4}$ cells were then added. After 24 and $48 \mathrm{~h}$ treatment, cell viability was measured by adding $12 \mu \mathrm{l} \mathrm{MTS}$ and incubating at $37^{\circ} \mathrm{C}$ for $2 \mathrm{~h}$ prior to reading absorbance at $490 \mathrm{~nm}$. The dual PLD1/PLD2 inhibitor FIPI was from Tocris, Bio-Techne Ltd, Abingdon, UK. Another dual PLD1/ PLD2 inhibitor 5W0 (VU0155056) and the specific PLD1 inhibitor EVJ (VU0359595) were gifts from Prof Alex Brown, Vanderbilt University, USA (Lavieri et al, 2009; Lewis et al, 2009; Lavieri et al, 2010).

Colony recovery assays. Patient-derived PCa cells were seeded in collagen 1 -coated 6 well plates at $2 \times 10^{5}$ cells per well in complete KSFM medium. The following day, cells were treated with either vehicle (DMSO) or a PLD inhibitor $(17.5 \mu \mathrm{M})$ for $4 \mathrm{~h}$. Cultures were then rinsed, trypsinised, counted and seeded at 500 cells per well of collagen 1-coated 6 well plates with STO feeder cells (Frame et al, 2013). The complete KSFM medium was changed regularly and further STOs added when required. After 2-3 weeks, colonies of $>32$ cells (at least 5 population doublings) were scored after being visualised by staining with $1 \%$ crystal violet in $10 \%$ ethanol in PBS.

Immunohistochemistry. Sections of formalin-fixed paraffinembedded normal, benign prostatic hyperplasia (BPH) and castrate-resistant prostate cancer (CRPC) tissue were warmed on a slide drier for $20 \mathrm{~min}$ at $45^{\circ} \mathrm{C}$, rehydrated through xylene and ethanol and then processed in a 2100 antigen-retriever (Aptum Biologics, Southampton, UK) for a two hour cycle in $10 \mathrm{mM}$ sodium citrate buffer, pH6 containing $0.05 \%$ Tween-20. For immunoperoxidase staining, slides were then rinsed three times in phosphate-buffered saline (PBS), blocked with $10 \%$ foetal calf serum (FCS) in PBS for one hour at room temperature (RT) and incubated with primary antibodies in $10 \%$ FCS in PBS overnight at $4{ }^{\circ} \mathrm{C}$ or for $2 \mathrm{~h}$ at RT. Sections were rinsed three times in PBS, treated with $3 \%$ hydrogen peroxide in PBS for $30 \mathrm{~min}$ to remove endogenous peroxidases and rinsed well in PBS. Secondary biotinylated antibody in 10\% FCS in PBS was then added for $30 \mathrm{~min}$ at room temperature followed by thorough rinsing in PBS. 
Table 1. Details of cell lines, diagnosis, source and media requirements

\begin{tabular}{|c|c|c|c|}
\hline Cell line & Diagnosis & Source/references & Culture medium \\
\hline PNT2C2 & $\begin{array}{l}\text { Normal prostate } \\
\text { epithelium }\end{array}$ & Obtained from ECACC (no longer available) & $\begin{array}{c}\text { RPMI } 1640+10 \% \text { foetal calf serum }(\text { FCS })+1 \% \\
\text { L-glutamine }\end{array}$ \\
\hline PNT1A & $\begin{array}{l}\text { Normal prostate } \\
\text { epithelium }\end{array}$ & $\begin{array}{c}\text { Kind gift to NJM's lab from P. Berthon. Currently available from } \\
\text { Health Protection Agency Culture Collections. }\end{array}$ & RPMI $1640+10 \%$ FCS + 1\% L-glutamine \\
\hline P4E6 & Prostate cancer & $\begin{array}{l}\text { Derived in York. Currently available from Health Protection Agency } \\
\text { Culture Collections }\end{array}$ & $\begin{array}{l}\text { KSFM }+1 \% \text { L-glutamine, bovine pituitary extract, } \\
\text { epidermal growth factor and } 2 \% \text { FCS }\end{array}$ \\
\hline VCaP & $\begin{array}{l}\text { Prostate cancer } \\
\text { bone metastasis }\end{array}$ & ATCC & RPMI $1640+10 \%$ FCS $+1 \%$ L-glutamine \\
\hline PC3 & $\begin{array}{l}\text { Prostate cancer } \\
\text { bone metastasis }\end{array}$ & ATCC & Hams F12 + 7\% FCS + 1\% L-glutamine \\
\hline PC3M & $\begin{array}{l}\text { Prostate cancer } \\
\text { bone metastasis }\end{array}$ & RRID:CVCL_9555 & Hams F12 + 7\% FCS + 1\% L-glutamine \\
\hline
\end{tabular}

Finally, sections were treated with streptavidin-HRP in 10\% FCS in PBS for $30 \mathrm{~min}$ at room temperature. After three rinses, sections were incubated with diaminobenzidene buffer (Vector kit or Sigma tablets) followed by extensive rinsing in PBS. Sections were counterstained with haematoxylin, rinsed with water and dehydrated through ethanol to xylene and mounted with DPX (Sigma Aldrich Company Ltd).

For immunofluorescence (IF), tissue sections were blocked with $10 \%$ FCS in PBS and incubated with primary antibody overnight at $4{ }^{\circ} \mathrm{C}$ in $10 \%$ FCS in PBS followed by further rinses. Secondary antibody in 10\% FCS in PBS was added for $1 \mathrm{~h}$ followed by rinses. Slides were mounted using Vectashield with DAPI to define nuclei (Vector laboratories, Peterborough, UK) and examined using a Nikon Eclipse TE300 fluorescence microscope (Nikon, Surrey, UK). Antibodies used were a polyclonal anti-PLD1 (sc25512) at $1: 100$, an anti-p63 (Dako M7317, Agilent Technologies, Stockport, UK) at $1: 100$, an anti-AMACR at 1:100 (Dako M3616), an antichromogranin A at 1:400 (Invitrogen LK2H10 Fisher Scientific Ltd), a goat anti-rabbit immunoglobulin/biotinylated (Dako E0432) at 1:500 and a rabbit anti-mouse immunoglobulin/ biotinylated (Dako E0354) at 1:200. Streptavidin-HRP (Dako, P0397) was used at $1: 100$.

Tissue microarray immunohistochemistry. A tissue microarray (TMA) of 41 kidney and 168 PCa tissue sections Gleason graded 6 $(n=43), 7(n=97), 8(n=13)$ or $9(n=15)$ from the Barts Cancer Institute was immunoperoxidase-stained for PLD1 as above. Stained sections were then scanned using a Zeiss AxioScan.Z1 slide scanner (ZEN 2012 software) with a Plan Apochromat $20 \times /$ 0.8 objective. The composite.czi files were loaded into Tissue Gnostics, GmbH, HistoQuest software (V 3.5.3) for analysis. The intensity of DAB staining was quantified using the workable area (mean $0.3 \mathrm{~mm}^{2}$ ) of each tissue section. The results were analysed in a GraphPad Prism statistical package (Graphpad Software, CA, USA).

\section{RESULTS}

PLD1 protein expression in prostate cell lines. With equal protein loadings $(30 \mu \mathrm{g})$, basal-like prostate epithelial cell lines PNT2C2, PNT1A, P4E6, and PC3 showed higher PLD1 protein expression than the luminal-like cell line LNCaP (Figure 1A). Two other luminal-like prostate epithelial cell lines VCaP and 22RV1 also expressed lower PLD1 protein compared with basal cell lines PNT2C2 and PC3 (Figure 1B). PLD1 protein expression in the

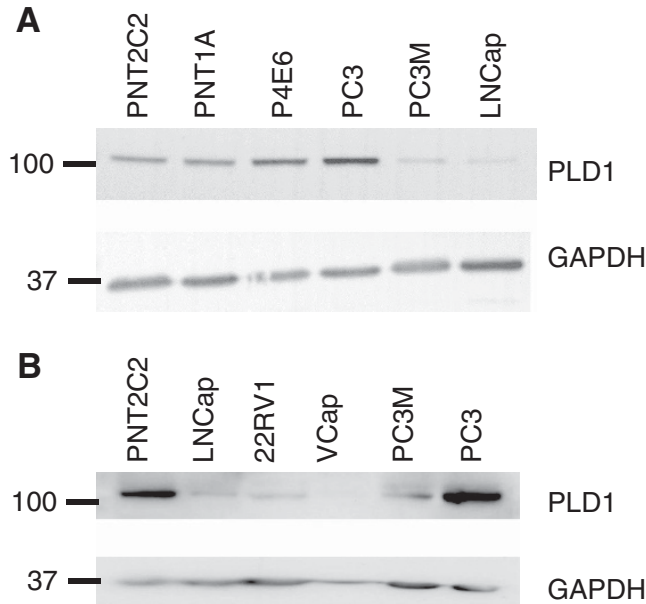

Figure 1. PLD1 protein expression in prostate epithelial cell lines. (A) PLD1 protein expression in normal and tumourigenic prostate epithelial cell lines. (B) PLD1 protein expression in luminal cell lines LNCaP, 22RV1 and VCaP. With all samples $30 \mu \mathrm{g}$ protein were resolved by SDS-PAGE for western blotting with detection of GAPDH as a loading control. Markers are $\mathrm{kDa}$. Blots shown are representative of several repeats. See Materials and Methods section for details.

metastatic PC3M cell line was much lower than in its parent cell line PC3.

PLD1 protein expression in patient-derived prostate epithelial and stromal cells. Cultured epithelial cells from Gleason 7 patient biopsies (Figure 2A) expressed PLD1 as did cells derived from prostate biopsies deemed to be normal $(\mathrm{N})$ on pathological examination. PLD1 protein expression was usually higher in cells from Gleason 7 samples compared with cells from normal tissue but differences did not achieve statistical significance. Prostate epithelial cells derived from benign prostatic hyperplasia $(\mathrm{BPH})$ tissue consistently had higher levels of PLD1 protein relative to cells from both normal and Gleason 7 prostate biopsies (Figure 2B). Stromal cells cultured from GL7 and GL9 tissue samples frequently expressed more PLD1 protein than the PC3 cell line or stromal cells purified from PCa tissue graded GL6 (Figure 2C).

PLD activity. Determination of PLD activity on tissue samples using the Amplex Red method gave results indicating that $\mathrm{BPH}$, 
A

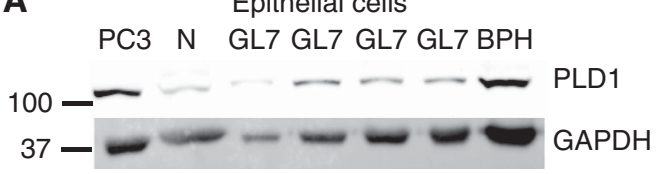

B

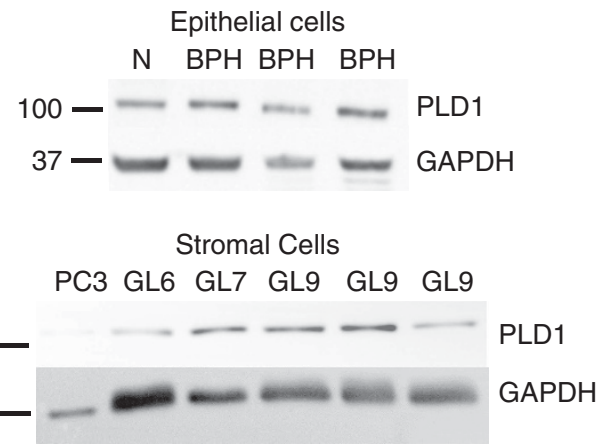

Figure 2. PLD1 protein expression in patient derived prostate cells. (A) PLD1 protein expression in epithelial cells derived from normal, $\mathrm{BPH}$ and Gleason 7 prostate tissue. (B) PLD1 protein expression in epithelial cells derived from normal and benign prostatic hyperplasia tissue. (C) PLD1 protein expression in stromal cells purified from prostate cancer tissue compared with PC3 cells. With all samples $30 \mu \mathrm{g}$ protein were resolved by SDS-PAGE for western blotting with GAPDH as loading control. Markers are $\mathrm{kDa}$. Blots shown are representative of several repeats. See Materials and Methods section for details. In Figure 2A and C, PC3 cells were included as a positive control for PLD1.

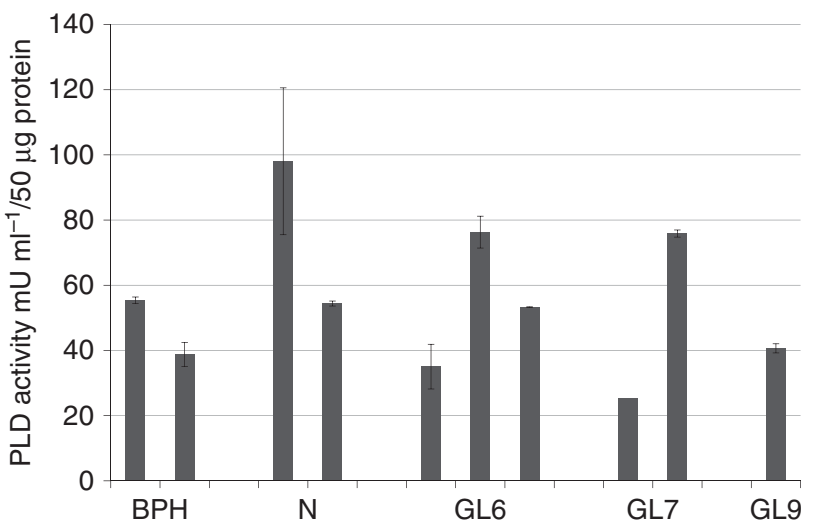

Figure 3. PLD activity in normal, BPH and Gleason-graded PCa tissue. Patient biopsy samples were extracted and analysed using a commercial Amplex Red PLD assay. $50 \mu \mathrm{g}$ total protein were assayed per sample. Error bars on BPH and GL9 samples are standard deviation where triplicate measurements were made or on normal, GL6 and GL7 samples are a range where only duplicate readings were made per sample due to limited availability of tissue. Lack of an error bar for one GL7 sample is because there was only sufficient biopsy tissue for a single reading.

normal, and PCa tissue samples have similar levels of PLD activity (Figure 3$)$. Error bars shown are the standard deviation $(n=3)$. The results without error bars are single results due to a limited amount of fresh biopsy tissue.

PLD inhibitors reduce cell viability in prostate epithelial cell lines. Changes in cell viability due to the actions of the dual PLD1/ PLD2 inhibitors FIPI and 5W0 (VU0155056) and a PLD1-specific inhibitor EVJ (VU0359595) were evaluated after 24 and $48 \mathrm{~h}$ treatment (Figure 4A). All three inhibitors reduced the viability of prostate epithelial cell lines. The specific PLD1 inhibitor (EVJ) was the most effective since at $25 \mu \mathrm{M}$ it reduced cell viability to almost zero after $48 \mathrm{~h}$ treatment. Cellular $\mathrm{IC}_{50}$ values calculated from the
MTS results using GraphPad prism (Table 2) confirmed that FIPI and 5W0 were not as effective at reducing cell viability as the specific PLD1 inhibitor EVJ.

PLD inhibitors reduce cell viability in patient-derived prostate epithelial cells. All the inhibitors reduced the viability of patientderived epithelial cells over the $0-25 \mu \mathrm{M}$ concentration range studied (Figure 4B). Again, the specific PLD1 inhibitor was more effective at reducing cell viability than FIPI and 5WO, especially with cells from patient 1 though in neither case was cell viability reduced to zero with $25 \mu \mathrm{M} \mathrm{EVJ}$, some $20 \%$ of the cell population still remaining viable after $48 \mathrm{~h}$ treatment. Cellular $\mathrm{IC}_{50}$ values (Table 2) confirmed this finding.

PLD inhibitors reduce colony forming ability in patient-derived prostate cells. Exposure of cells from tissue from eight different PCa patients to $17.5 \mu \mathrm{M}$ EVJ for $4 \mathrm{~h}$ significantly $(P=<0.001)$ reduced subsequent colony formation ( $>32$ cells) relative to DMSO vehicle controls (Figure 5) measured 2 weeks later. The median reduction relative to controls by the PLD1 inhibitor EVJ was about $30 \%$. Of the eight patient samples treated with EVJ, five showed a uniform $25 \%$ reduction in colony-forming ability while three were more seriously affected.

PLD1 localisation in BPH tissue sections. Serial sections of $\mathrm{BPH}$ tissue were stained for PLD1, p63 as a positive control for basal cells and DAPI to reveal all cell nuclei. By IF, PLD1 protein was detected as perinuclear punctate staining predominantly in basal cells around prostate acini (Figure 6A, PLD1, arrows) compared with the nuclear p63 positive control (Figure 6A, p63, arrow). The merged images show that PLD1 is predominately expressed in basal cells. The enlarged IF image in Figure 6B (arrows) reveals the perinuclear punctate staining of PLD1 in the basal cells. This localisation of PLD1 to basal cells in BPH tissue was confirmed by immunoperoxidase staining. As shown in Figure 6C, PLD1positive cells (arrows) matching the distribution of the basal cell marker p63 underlie a layer of light blue luminal cells lining the duct. Both immunohistochemical approaches revealed that some stromal cells in BPH tissue expressed PLD1.

PLD1 localisation in normal and tumourigenic prostate tissue samples. In tissue sections from a normal biopsy, PLD1 expression was detected by IHC in the nuclei and cytoplasm of rounded and elongated cells throughout the stroma, as well as prominently in basal cells round defined glands (Figure 7B, arrows). Lower PLD1 protein expression was also detected in luminal cell nuclei and cytoplasm (Figure 7B, arrow). In sections from a biopsy core graded Gleason 7, PLD1 protein was detected in elongated cells throughout the stroma as well as in the cytoplasm and nuclei of luminal cells (Figure 7C, arrows). In serial sections, these elongated PLD1-positive stromal cells also expressed smooth muscle actin (not shown). In CRPC tissue, PLD1 expression was detected in the cytoplasm and nuclei of many stromal cells (Figure 7D, arrows) and prominently in the cytoplasm of tightly packed cells (Figure 7D, *) that, in serial sections, stained positively for chromogranin A (Figure $7 \mathrm{E}^{\star}$ ). A second antibody control of morphologically normal prostate tissue showed no peroxidase staining (Figure 7A).

PLD1 expression in a PCa tissue microarray. All PCa tissue sections graded Gleason 6-9 on a TMA showed PLD1 expression in the cytoplasm and nuclei of luminal cells in glands, some of which contained crystalloids (not shown). PLD1 expression was detected in scattered cells throughout the stroma in all sections examined. Some luminal cells showed intense PLD1 staining at their apical surfaces. Quantitative and statistical analysis using the GraphPad package revealed that the median peroxidase staining intensity of GL6 and GL7 sections was significantly $\left({ }^{*} P<0.05\right)$ higher than that of GL9 sections (Figure 8). Control kidney tissue 
A
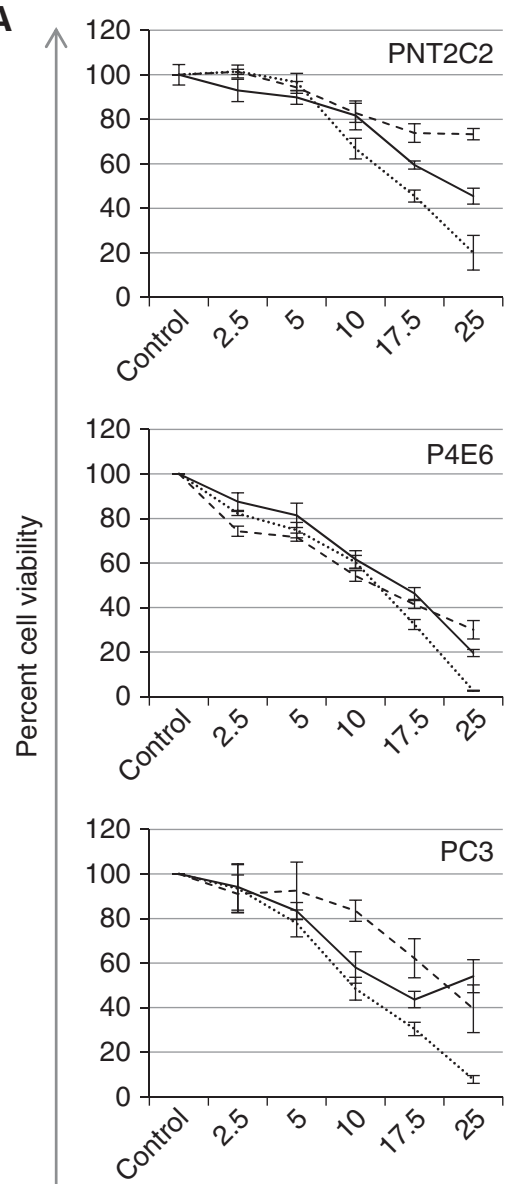
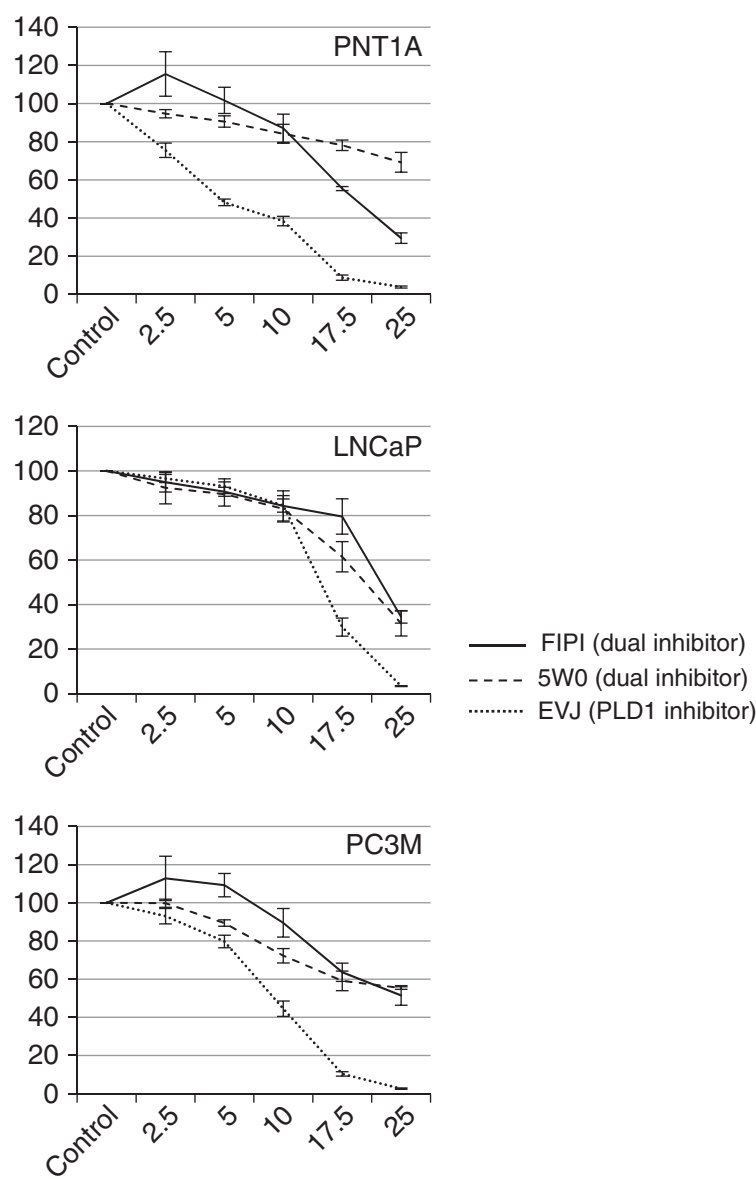

Drug concentration $(\mu \mathrm{M})$

B

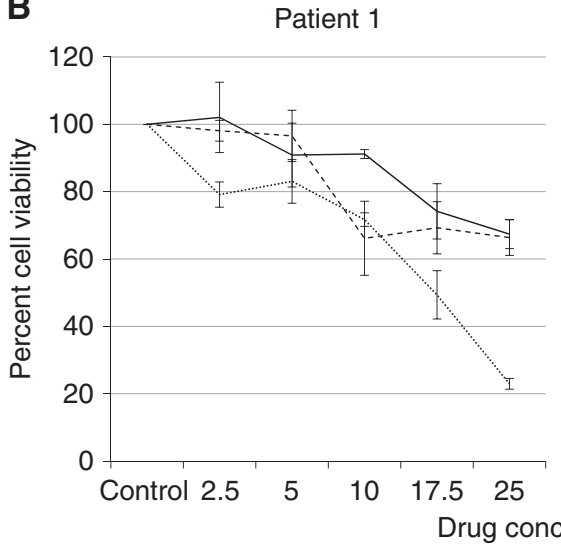

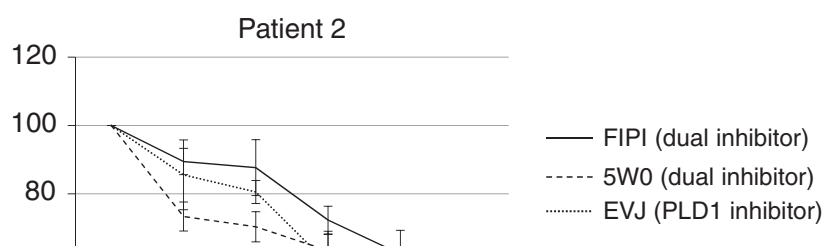

Figure 4. Effect of PLD inhibitors on prostate epithelial cell viability. (A) prostate cell lines, (B) patient-derived prostate epithelial cells. The cells were cultured with 0-25 $\mu \mathrm{M}$ concentrations of the dual PLD1/PLD2 inhibitors FIPI and 5W0 and the PLD1-specific inhibitor EVJ. Inhibitors were dissolved in DMSO. Cell viability was measured by MTS assay after $48 \mathrm{~h}$. Results are expressed as percentage cell viability relative to DMSO controls.

sections on the TMA showed positive PLD1 staining in epithelial layer cells lining most tubules.

\section{DISCUSSION}

The current consensus that PLD is involved in tumourigenesis (Jenkins and Frohman, 2005; Cazzolli et al, 2006; Wang et al, 2006; Foster, 2009; Winter et al, 2010; Kang et al, 2011; Henkels et al,
2013; Brown et al, 2017) has stimulated the development of new inhibitors specific for PLD1 and PLD2 that are well tolerated in mice (Scott et al, 2009). Although it is the major cancer of men in the Western world, surprisingly little is known about the expression and activity of PLD1 and PLD2 in PCa. In this first report on PLD isoforms in PCa, we have investigated PLD1 using a commercial anti-PLD1 antibody (sc-25512), which has been validated for western blotting (Disse et al, 2009; Scott et al, 2009; Chen et al, 2013) and which has also been used to detect PLD1 in cells by immunofluorescence (Disse 
Table 2. Inhibitor $I_{50}$ values for FIPI, 5 W0 and EVJ effects on cell viability as calculated from the MTS assay results using a Prism package

\begin{tabular}{|l|c|c|c|}
\cline { 2 - 4 } & \multicolumn{3}{c|}{ Inhibitor IC 5 values $(\boldsymbol{\mu m})$} \\
\hline Cell type & FIPI & $\mathbf{5 W 0}$ & EVJ \\
\hline PNT2C2 & 28.2 & 60.4 & 17.3 \\
\hline PNT1A & 27.1 & 56.8 & 4.7 \\
\hline P4E6 & 13.6 & 10.9 & 9.4 \\
\hline LNCaP & 32 & 24.6 & 14.3 \\
\hline PC3 & 19.3 & 27.3 & 9.8 \\
\hline PC3M & 42.9 & 29.8 & 8.0 \\
\hline Patient 1 & 57.6 & 39.8 & 14.8 \\
\hline Patient 2 & 30.1 & 13.9 & 12.0 \\
\hline
\end{tabular}

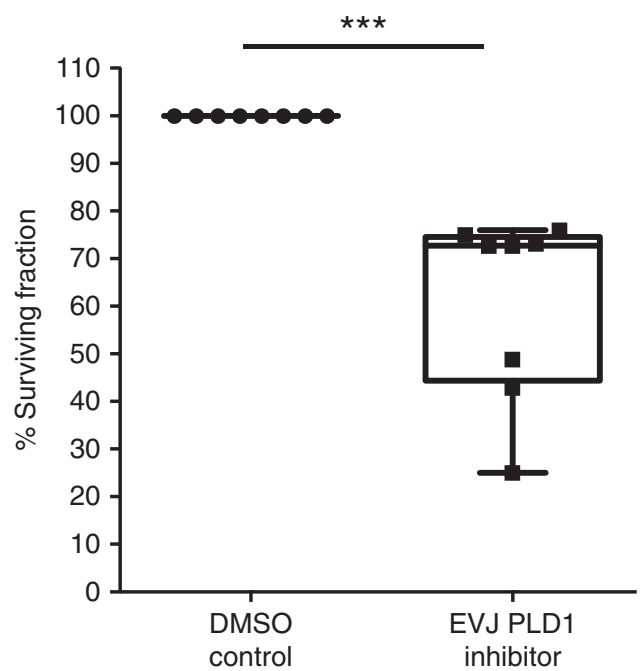

Figure 5. Effect of PLD1 inhibitor on colony recovery in patientderived prostate epithelial cells. Patient-derived cells cultured from prostate cancer biopsies were treated with $17.5 \mu \mathrm{M}$ EVJ (PLD1 inhibitor) for $4 \mathrm{~h}$ prior to re-plating cells at low density without inhibitor with STO feeder cells. Two weeks later, colonies of $>32$ cells were counted and their number expressed relative to controls (DMSO vehicle only). A Mann-Whitney test gave a significance of $* \star * P<0.001$. See Materials and Methods section for details.

et al, 2009; Han et al, 2011). We have not examined PLD2 expression in this work since, in agreement with Scott (Scott et al, 2009), we have found commercial anti-PLD2 antibodies to be unreliable.

PLD1 protein expression in prostate epithelial cell lines. We used the same panel of prostate epithelial cell lines as previously (Rumsby et al, 2011; Schmitt et al, 2014) to examine PLD1 protein expression in cells spanning the normal to metastatic extremes of PCa (Figure 1A). We added PC3M cells, a more metastatic cell line derived from PC3 cells. The finding that PLD1 protein expression was lower in PC3M cells compared with the parent PC3 cell line suggests that a PLD1-PtdOH-mTOR pathway may be less important for metastasis in prostate epithelial cells compared with other reported pathways such as an oncogene-tumour suppressor cascade (Min et al, 2010), DNA-PKcs-Mediated Transcriptional Regulation (Goodwin et al, 2015) and/or the tumour microenvironment (Mlecnik et al, 2016). Luminal LNCaP cells expressed the

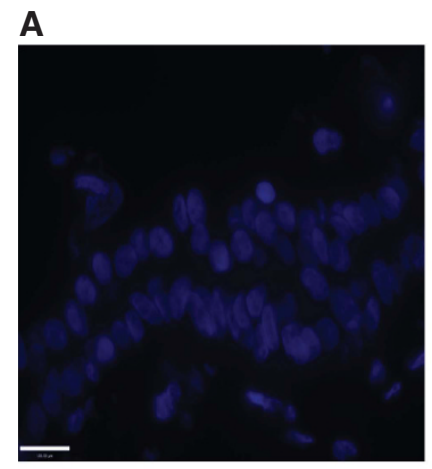

DAPI

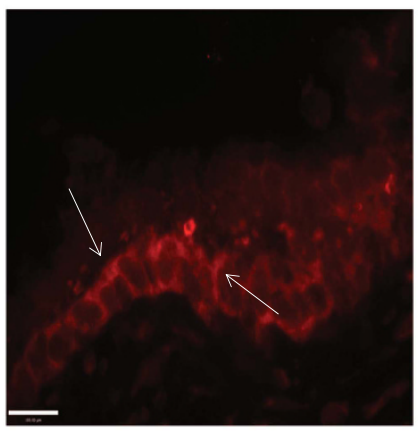

PLD1

B

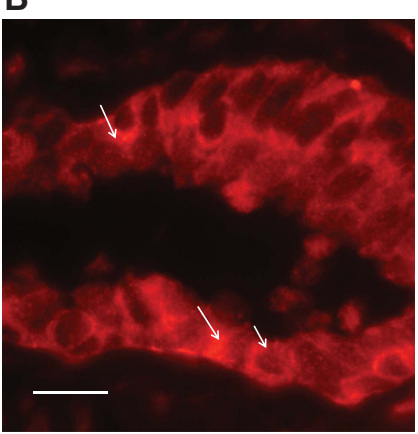

C
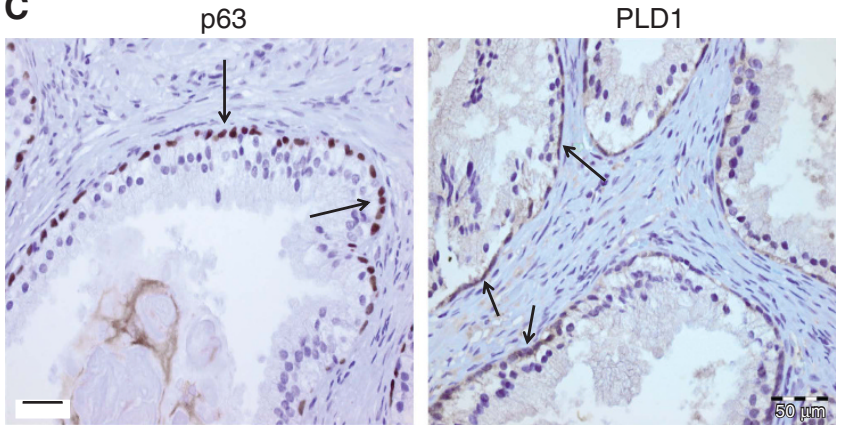

Figure 6. PLD1 is expressed in basal cells in BPH tissue.

(A) Immunofluorescence: DAPI staining for nucleii, p63 marker for basal cells, PLD1 (arrows indicate perinuclear PLD1 staining), and merged images (scale bars $100 \mu \mathrm{M}$ ). (B) IF PLD1 in BPH tissue showing the perinuclear punctate pattern of expression (scale bar $90 \mu \mathrm{M}$ )

(C) Immunoperoxidase: BPH tissue stained for the basal cell marker p63 (arrows) and PLD1 (arrows). Scale bars: $50 \mu \mathrm{M}$. See Materials and Methods section for details of techniques.

lowest levels of PLD1 compared with the basal cell lines especially PC3 cells. This prompted us to check PLD1 protein expression in two other luminal prostate cell lines, 22RV1 derived from a tumour xenograft and VCaP derived from a PCa bone metastasis 

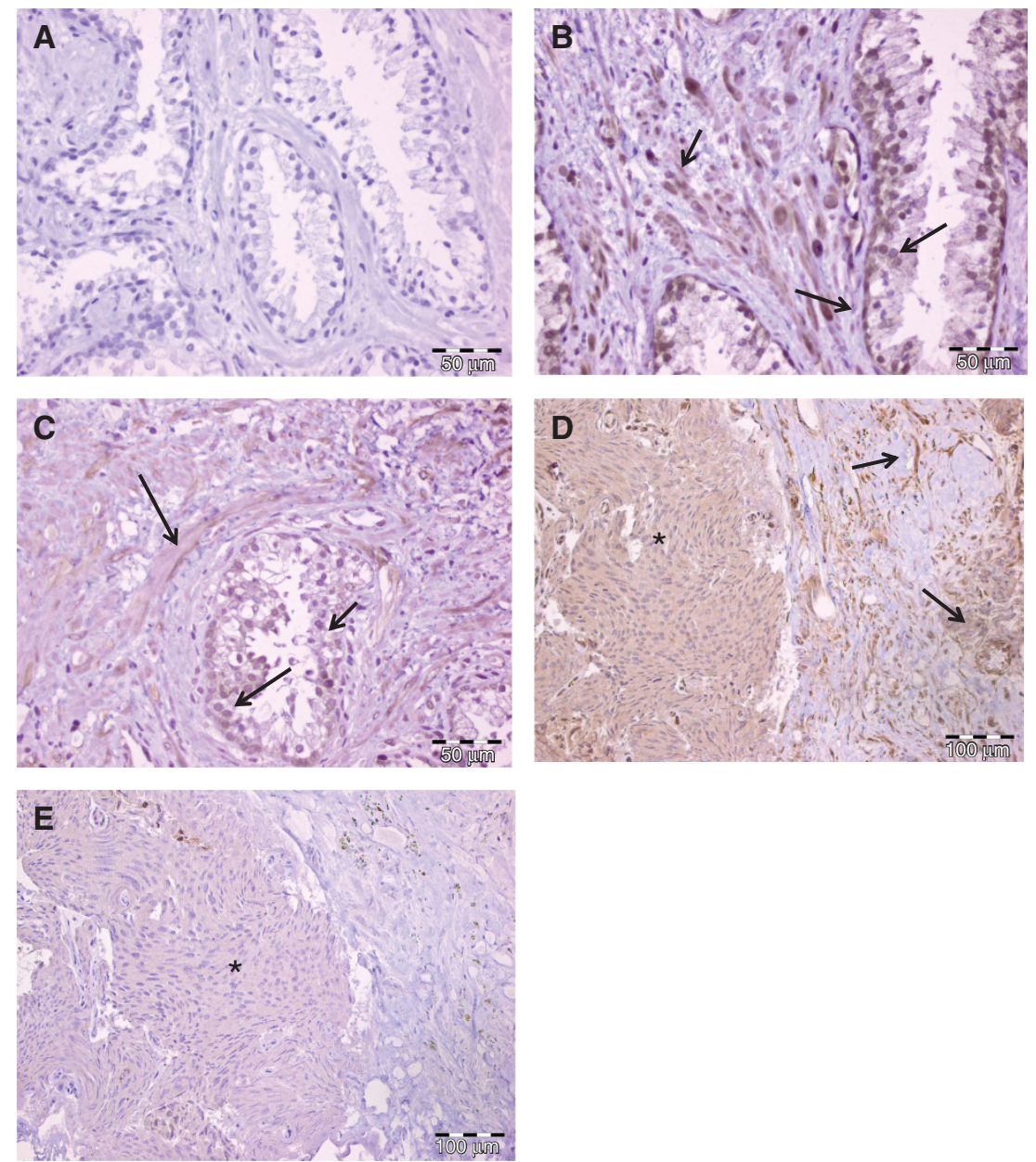

Figure 7. PLD1 protein expression in normal and tumourigenic prostate tissue. (A) Secondary antibody control, normal prostate tissue, (B) typical PLD1 expression in normal prostate tissue, (C) PLD1 expression in Gleason 7 PCa tissue, (D) PLD1 expression in castrate-resistant PCa tissue and (E) serial section of tissue in (D) showing cells staining positive for chromogranin (A) (*). Scale bar: (A-D) $50 \mu M$, (E) $100 \mu$ M. See Materials and Methods section for details of techniques.

(Figure 1B). The finding that both had very low PLD1 protein expression similar to LNCaP cells reveals that basal and luminal prostate epithelial cell lines differ significantly in PLD1 protein expression.

This difference helps explain our previous results (Rumsby et al, 2011), where activation of protein kinase C (PKC) markedly stimulated choline headgroup release due to PLD1 activity in basal PC3 cells, while luminal LNCaP cells showed a very weak response. The difference would also explain our subsequent results (Schmitt et al, 2014) where stimulation of PKC in PC3 cells, but not in LNCaP cells, resulted in a rapid release of ethanolamine to the culture medium due to an increased turnover of ethanolamine phospholipids by PLD1. Our earlier results thus support this new finding that basal and luminal prostate epithelial cell lines differ significantly in their levels of PLD1 expression.

PLD1 protein expression in cells purified from prostate tissue. Biopsy cores from different lobes of the prostate frequently show $\mathrm{PCa}$ in one lobe and no cancer in the other. We exploited such differences to isolate epithelial cells from biopsies of the same patient's prostate, which had been classified as malignant or nonmalignant (normal). All cells whether cultured from nonmalignant or malignant biopsy cores, or from TURPS (BPH or high Gleason samples) expressed PLD1 at levels that were usually lower than detected in the basal PC3 cell line. These biopsy-derived epithelial cell cultures are predominately basal in phenotype since stromal and luminal cells are removed during preparation (Collins et al, 2001; Frame et al, 2016). PLD1 expression varied considerably (Figure 2A) between cell preparations cultured from $\mathrm{PCa}$ tissue of a similar Gleason grade. It was not routinely higher in cultures derived from malignant prostate biopsies as reported for some other cancers (Uchida et al, 1997; Uchida et al, 1999; Noh et al, 2000; Zhao et al, 2000; Saito et al, 2007). Such differences in PLD1 protein expression between cells isolated from PCa tissue of similar Gleason grade probably reflect inter-patient and biopsy variation. Significantly, however, epithelial cells cultured from BPH tissue consistently showed higher PLD1 protein expression compared with cells cultured from non-malignant or PCa tissue (Figure 2B). In $\mathrm{BPH}$, basal, luminal and stromal cell numbers increase in the periurethral transition zone of the prostate (Dermer, 1978; Bonkhoff et al, 1994; Roehrborn, 2008; Rane et al, 2016) because of increased proliferation, or impaired programmed cell death, from the influence of androgens, oestrogens and reactive stromal growth factors (Roehrborn, 2008; Schauer and Rowley, 2011). The increased PLD1 protein expression we observe in these basal cell cultures could enhance the cellular proliferative changes observed in BPH tissue. This is because stromal growth factors such as EGF and IGF can stimulate PKC (Griner and Kazanietz, 2007; Lemmon and Schlessinger, 2010; Dowling and Kiely, 2015) thereby activating PLD1 and increasing PtdOH formation and mTOR signalling (Foster, 2009; Zhou and Huang, 2011). 


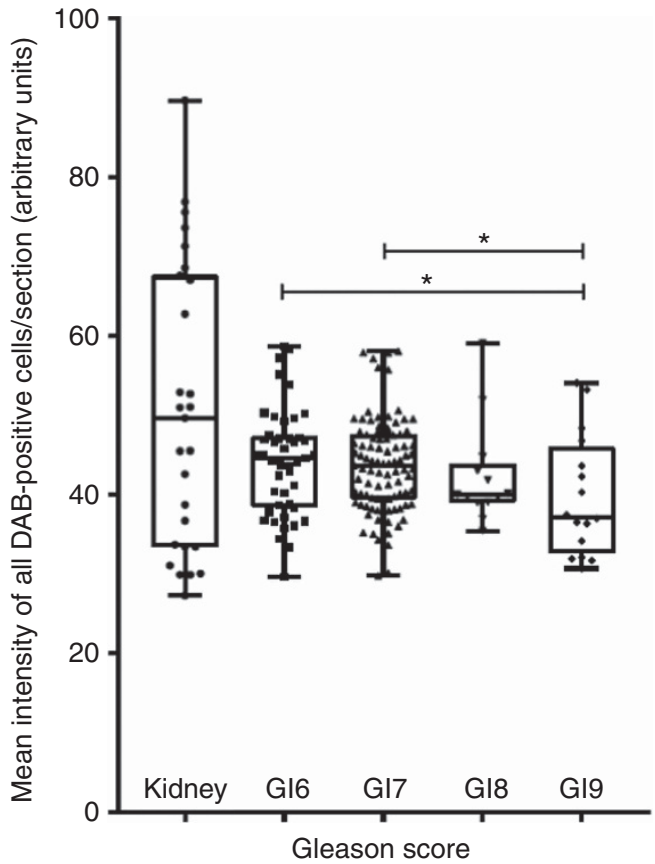

Figure 8. Quantification of DAB stain intensity of PLD1 protein in relation to Gleason grade in a tissue microarray. Over 150 PCa tissue sections were analysed for PLD1 expression in a tissue microarray as described in Materials and Methods section. Tissue sections graded GL6 and 7 have a significantly higher mean peroxidase stain intensity compared with GL9 sections ( $\left.{ }^{\star} P<0.05\right)$.

PLD1 protein expression in non-malignant, malignant and $\mathrm{BPH}$ prostate tissue. Our IF and IHC results show that PLD1 is preferentially expressed in basal rather than luminal epithelial cells in situ in non-malignant and BPH tissue (Figures 6 and 7) in agreement with western blot results on cells. Basal cells expressing PLD1 are not observed in malignant tissue (Figure 7C) where proliferative luminal cells predominate (Jonathan and Epstein, 2008). The increased PLD1 expression observed in the expanding luminal compartment detected in PCa tissue (Figure 7C) may be regulating part of this proliferation process. If so, the TMA results suggest that PLD1 expression may play a more significant role in prostate tumours graded Gleason 6 or 7 compared with the more severe Gleason 9 stage. This agrees with our finding that more metastatic PC3M cells had lower levels of PLD1 expression than the less metastatic PC3 parental cell line.

The perinuclear punctate distribution of PLD1 in the cytosol of prostate basal cells as revealed by IF (Figure 6B) is in keeping with results by others using IF and overexpression methods (Brown et al, 1998; Cockcroft, 2001; Freyberg et al, 2001; Lucocq et al, 2001; Du et al, 2003; Disse et al, 2009; Han et al, 2011) or other anti-PLD1 antibodies (Freyberg et al, 2001; Vitale et al, 2001). These results suggest a role for PLD1 in regulated exocytosis involving lysosomes and endosomes and the generation of $\mathrm{PtdOH}$ for second messenger effects at the plasma membrane notably on mTOR and Raf (Foster et al, 2014). Our IHC detection of PLD1 in the nucleus of stromal and luminal cells in PCa is significant because nuclear PLD1 can activate a local nuclear PKC $\alpha$ and ERK signalling pathway to stimulate cell proliferation (Jang and Min, 2012). This can be regulated by several cell surface signalling pathways (Baldassare et al, 1997; Gayral et al, 2006; Ushio-Fukai, 2006; Jang and Min, 2012). Nuclear PLD1 is also linked to diacylglycerol formation, which regulates entry of PKC isoforms into the nucleus with effects on cell proliferation, gene expression and malignancy (Martelli et al, 2004; Tu-Sekine and Raben, 2004; Martelli et al, 2006). Stroma in non-malignant prostate tissue contains mainly smooth muscle cells (Hagglof and Bergh, 2012) and our finding that such cells co-express PLD1 is not surprising since vascular smooth muscle cells also express PLD1 (Gayral et al, 2006). However, detection of PLD1 in CRPC, an incurable and aggressive terminal stage of PCa (Katsogiannou et al, 2015), is intriguing. Stromal cells that express PLD1 (Figures 2C and 7) also express smooth muscle actin so are likely to be myofibroblasts (Figure 7D) as smooth muscle cells decline in CRPC (Hagglof and Bergh, 2012). Such cells secrete a variety of growth factors (Hagglof and Bergh, 2012), which will activate PLD1 stimulating local cell proliferation. In CRPC tissue, these growth factors may also influence proliferation of the densely packed cells, which express PLD1 in their cytoplasm (Figure 7D and $\mathrm{E}^{\star}$ ). We showed that these cells co-express chromogranin A ( CgA), a marker for neuroendocrine cells (Deftos et al, 1996; Sun et al, 2009) and thus show focal neuroendocrine differentiation (Terry and Beltran, 2014). We find that similar PLD1-expressing cells in CRPC tissue also co-express neurone-specific enolase (NSE), another neuroendocrine cell marker (Deftos et al, 1996; Sun et al, 2009). These CgA- and NSE-expressing neuroendocrine-like cells are indicative of a poor prognosis (Terry and Beltran, 2014) and may arise from adenocarcinoma cells by neuroendocrine transdifferentiation involving IL-6 among other factors (Terry and Beltran, 2014; Grigore et al, 2015). PLD1 in the cytosol of these neuroendocrinelike cells may play a role in exocytosis important for cell proliferation (Vitale et al, 2001) and may also regulate cell growth through the generation of PtdOH and its links to Wnt signalling pathways (Kang et al, 2011).

PLD activity. The anomaly that PLD1 protein expression in $\mathrm{BPH}$ tissue samples is higher than in normal or PCa tissue, while PLD activity in the two $\mathrm{BPH}$ tissue samples measured is not raised above values for normal and PCa tissue may arise for two reasons. Firstly, PLD1 protein expression was measured in cultured cells from BPH tissue that are largely basal in phenotype, while PLD activity was assayed in whole BPH tissue samples which contain stromal and luminal cells as well as basal cells (Schauer and Rowley, 2011). Secondly, any nuclear PLD1 detected in BPH tissue by IHC would not have been assayed since these organelles would be removed during centrifugation to pellet cell debris. With these caveats, our activity results suggest that, unlike in breast adenocarcinomas and other cancers (see Introduction), PLD activity in PCa is not raised compared to normal tissue.

PLD inhibition. The potent effects of the new generation of PLD1 and PLD2 inhibitors (Monovich et al, 2007; Lavieri et al, 2009; Lewis et al, 2009; Scott et al, 2009; Lavieri et al, 2010) on cell survival show the importance of PLD isoforms in controlling prostate epithelial cell proliferation (Foster, 2009; Winter et al, 2010; Kang et al, 2011; Yoon et al, 2011). It should be noted that our IC $_{50}$ values (Table 2) are higher than those reported for the specific inhibition of PLD1 (Scott et al, 2009; Lavieri et al, 2010). This is because our cells were cultured in serum-containing medium under which conditions greater than 95\% of these lipophilic inhibitors can become protein bound (Lavieri et al, 2010; Mathews et al, 2015). Our inhibitor concentrations in the $\mu \mathrm{M}$ range are in agreement with other reports for the effects of these PLD inhibitors on cells growing in serum-supplemented medium (Lavieri et al, 2010; Liu et al, 2013; Mathews et al, 2015). Mathews et al (2015) report that at $5-10 \mu \mathrm{M}$ sufficient inhibitor is still available for subtype-selective inhibition of PLD1 in cells growing in serum-supplemented medium. The $\mathrm{IC}_{50}$ values in Table 2 indicate that basal PC3 cells are more sensitive to PLD inhibitors than luminal LNCaP cells presumably because they express more PLD protein. The cells from two Gleason 7 patient tissues growing in serum free medium plus additives are also sensitive to the specific PLD1 inhibitor. Their $\mathrm{IC}_{50}$ values are similar to those for metastatic PC3 and PC3M cells because such patient derived 
prostate cells are often more resistant to treatments than cell lines (Ulukaya et al, 2013; Butler et al, 2017). We are now investigating the effects of the specific PLD2 inhibitor JWJ (VU0364739) on prostate cancer cell survival since this isoform has both enzymatic and GEF functions (Kang et al, 2014), which may give it a more direct role in proliferation, cell adhesion, migration and invasion (Chae et al, 2010).

The fact that a brief four hour exposure of cells to EVJ had a damaging effect on colony formation 2 weeks later indicates that short term inhibition of PLD1 has significant long term effects on PCa cell viability. That subsequent colony formation by PCa cells from three patients was more seriously affected by initial EVJ treatment than the five others must reflect differences such as stage of disease in the PCa biopsies from which the cells were purified. Our observations on EVJ effects on colony formation and cell viability suggest that this new specific PLD1 inhibitor has similar potential for treating PCa as already shown for breast cancer models in mice (Scott et al, 2009). In this connection, it is relevant that the antipsychotic agent halopemide, on which these new inhibitors are based, is well tolerated in humans and has been tested in clinical trials (Loonen and Soudijn, 1985; Lindsley and Brown, 2012). EVJ could be used as a combination therapy alongside hormone/anti-androgen treatments that target luminal cells in PCa. PLD inhibition has also been shown to sensitise cancer cells to radiotherapy (Cheol Son et al, 2013) opening up further possible therapeutic applications.

\section{ACKNOWLEDGEMENTS}

Much of this work was carried out when ARN was a Daphne Jackson Research Fellow with funding from Prostate Cancer UK. This work was also supported by funding to NJM from Yorkshire Cancer Research (Y259PA) and from PCUK Innovation award RIA15-ST2-022, to DMB from Orchid (MIMG1L6R) and to ARN and MGR from the Cancer and Polio Research Fund. We thank the surgeons and patients from Castle Hill Hospital, Cottingham, Hull for providing prostate biopsy tissue and Sakunthala Kudahetti at the Barts Cancer Centre for tissue microarrays. Thank you to Prof. Alex Brown Vanderbilt University, for the PLD inhibitors. Joanne Marrison and Dr Karen Hogg (Bioscience Technology Facility, University of York) are thanked for help with TMA analysis and quantitation.

\section{CONFLICT OF INTEREST}

The authors declare no conflict of interest.

\section{REFERENCES}

Ahn BH, Min G, Bae YS, Bae YS, Min DS (2006) Phospholipase D is activated and phosphorylated by casein kinase-II in human U87 astroglioma cells. Exp Mol Med 38(1): 55-62.

Baldassare JJ, Jarpe MB, Alferes L, Raben DM (1997) Nuclear translocation of RhoA mediates the mitogen-induced activation of phospholipase D involved in nuclear envelope signal transduction. J Biol Chem 272(8): 4911-4914.

Bonkhoff H, Stein U, Remberger K (1994) The proliferative function of basal cells in the normal and hyperplastic human prostate. Prostate 24(3): 114118.

Brown FD, Thompson N, Saqib KM, Clark JM, Powner D, Thompson NT, Solari R, Wakelam MJ (1998) Phospholipase D1 localises to secretory granules and lysosomes and is plasma-membrane translocated on cellular stimulation. Curr Biol 8(14): 835-838.
Brown HA, Thomas PG, Lindsley CW (2017) Targeting phospholipase D in cancer, infection and neurodegenerative disorders. Nat Rev Drug Discov 16(5): 351-367.

Butler DE, Marlein C, Walker HF, Frame FM, Mann VM, Simms MS, Davies BR, Collins AT, Maitland NJ (2017) Inhibition of the PI3K/AKT/mTOR pathway activates autophagy and compensatory Ras/Raf/MEK/ERK signalling in prostate cancer. Oncotarget 8(34): 56698-56713.

Cazzolli R, Shemon AN, Fang MQ, Hughes WE (2006) Phospholipid signalling through phospholipase D and phosphatidic acid. IUBMB Life 58(8): 457-461.

Chae YC, Kim KL, Ha SH, Kim J, Suh PG, Ryu SH (2010) Protein kinase Cdelta-mediated phosphorylation of phospholipase D controls integrinmediated cell spreading. Mol Cell Biol 30(21): 5086-5098.

Chen F, Ghosh A, Shneider BL (2013) Phospholipase D2 mediates signaling by ATPase class I type $8 \mathrm{~B}$ membrane 1. J Lipid Res 54(2): 379-385.

Cheol Son J, Woo Kang D, Mo Yang K, Choi KY, Gen Son T, Min do S (2013) Phospholipase D inhibitor enhances radiosensitivity of breast cancer cells. Exp Mol Med 45: e38.

Cockcroft S (2001) Signalling roles of mammalian phospholipase D1 and D2. Cell Mol Life Sci 58(11): 1674-1687.

Collins AT, Habib FK, Maitland NJ, Neal DE (2001) Identification and isolation of human prostate epithelial stem cells based on alpha(2)beta(1)integrin expression. J Cell Sci 114(Pt 21): 3865-3872.

Deftos LJ, Nakada S, Burton DW, di Sant'Agnese PA, Cockett AT, Abrahamsson PA (1996) Immunoassay and immunohistology studies of chromogranin A as a neuroendocrine marker in patients with carcinoma of the prostate. Urology 48(1): 58-62.

Dermer GB (1978) Basal cell proliferation in benign prostatic hyperplasia. Cancer 41(5): 1857-1862.

Disse J, Vitale N, Bader MF, Gerke V (2009) Phospholipase D1 is specifically required for regulated secretion of von Willebrand factor from endothelial cells. Blood 113(4): 973-980.

Dowling CM, Kiely PA (2015) Targeting protein Kinase C downstream of growth factor and adhesion signalling. Cancers 7(3): 1271-1291.

Du G, Altshuller YM, Vitale N, Huang P, Chasserot-Golaz S, Morris AJ, Bader MF, Frohman MA (2003) Regulation of phospholipase D1 subcellular cycling through coordination of multiple membrane association motifs. J Cell Biol 162(2): 305-315.

Foster DA (2009) Phosphatidic acid signaling to mTOR: signals for the survival of human cancer cells. Biochim Biophys Acta 1791(9): 949-955.

Foster DA, Salloum D, Menon D, Frias MA (2014) Phospholipase D and the maintenance of phosphatidic acid levels for regulation of mammalian target of rapamycin (mTOR). J Biol Chem 289(33): 22583-22588.

Foster DA, Xu L (2003) Phospholipase D in cell proliferation and cancer. Mol Cancer Res 1(11): 789-800.

Frame FM, Pellacani D, Collins AT, Maitland NJ (2016) Harvesting human prostate tissue material and culturing primary prostate epithelial cells. Methods Mol Biol 1443: 181-201.

Frame FM, Pellacani D, Collins AT, Simms MS, Mann VM, Jones GD, Meuth M, Bristow RG, Maitland NJ (2013) HDAC inhibitor confers radiosensitivity to prostate stem-like cells. Br J Cancer 109(12): 3023-3033.

Freyberg Z, Sweeney D, Siddhanta A, Bourgoin S, Frohman M, Shields D (2001) Intracellular localization of phospholipase D1 in mammalian cells. Mol Biol Cell 12(4): 943-955.

Gayral S, Deleris P, Laulagnier K, Laffargue M, Salles JP, Perret B, Record M, Breton-Douillon M (2006) Selective activation of nuclear phospholipase D-1 by G protein-coupled receptor agonists in vascular smooth muscle cells. Circ Res 99(2): 132-139.

Goodwin JF, Kothari V, Drake JM, Zhao S, Dylgjeri E, Dean JL, Schiewer MJ, McNair C, Jones JK, Aytes A, Magee MS, Snook AE, Zhu Z, Den RB, Birbe RC, Gomella LG, Graham NA, Vashisht AA, Wohlschlegel JA, Graeber TG, Karnes RJ, Takhar M, Davicioni E, Tomlins SA, Abate-Shen C, Sharifi N, Witte ON, Feng FY, Knudsen KE (2015) DNA-PKcs-mediated transcriptional regulation drives prostate cancer progression and metastasis. Cancer Cell 28(1): 97-113.

Grigore AD, Ben-Jacob E, Farach-Carson MC (2015) Prostate cancer and neuroendocrine differentiation: more neuronal, less endocrine? Front Oncol 5: 37.

Griner EM, Kazanietz MG (2007) Protein kinase C and other diacylglycerol effectors in cancer. Nat Rev Cancer 7(4): 281-294. 
Hagglof C, Bergh A (2012) The stroma-a key regulator in prostate function and malignancy. Cancers 4(2): 531-548.

Hall CL, Keller ET (2006) The role of Wnts in bone metastases. Cancer Metastasis Rev 25(4): 551-558.

Han X, Yu R, Zhen D, Tao S, Schmidt M, Han L (2011) beta-1,3-Glucaninduced host phospholipase $\mathrm{D}$ activation is involved in Aspergillus fumigatus internalization into type II human pneumocyte A549 cells. PloS ONE 6(7): e21468.

Henkels KM, Boivin GP, Dudley ES, Berberich SJ, Gomez-Cambronero J (2013) Phospholipase D (PLD) drives cell invasion, tumor growth and metastasis in a human breast cancer xenograph model. Oncogene 32(49): 5551-5562.

Henkels KM, Peng HJ, Frondorf K, Gomez-Cambronero J (2010) A comprehensive model that explains the regulation of phospholipase D2 activity by phosphorylation-dephosphorylation. Mol Cell Biol 30(9): 22512263.

Jang YH, Min DS (2012) The hydrophobic amino acids involved in the interdomain association of phospholipase D1 regulate the shuttling of phospholipase D1 from vesicular organelles into the nucleus. Exp Mol Med 44(10): 571-577.

Jenkins GM, Frohman MA (2005) Phospholipase D: a lipid centric review. Cell Mol Life Sci 62(19-20): 2305-2316.

Jonathan I, Epstein GJN (2008) Biopsy Interpretation of the Prostate. 4th edn: Wolters Kuwer.

Kang DW, Choi K-Y, Min DS (2014) Functional Regulation of Phospholipase D Expression in Cancer and Inflammation. J Biol Chem 289(33): 22575-22582.

Kang DW, Choi KY, Min do S (2011) Phospholipase D meets Wnt signaling: a new target for cancer therapy. Cancer Res 71(2): 293-297.

Katsogiannou M, Ziouziou H, Karaki S, Andrieu C, Henry de Villeneuve M, Rocchi P (2015) The hallmarks of castration-resistant prostate cancers. Cancer Treat Rev 41(7): 588-597.

Kim Y-R, Byun HS, Won M, Park KA, Kim JM, Choi BL, Lee H, Hong JH, Park J, Seok JH, Kim DW, Shong M, Park S-K, Hur GM (2008) Modulatory role of phospholipase D in the activation of signal transducer and activator of transcription (STAT)-3 by thyroid oncogenic kinase RET/ PTC. BMC Cancer 8(1): 144

Kim Y, Han JM, Han BR, Lee KA, Kim JH, Lee BD, Jang IH, Suh PG, Ryu SH (2000) Phospholipase D1 is phosphorylated and activated by protein kinase $\mathrm{C}$ in caveolin-enriched microdomains within the plasma membrane. J Biol Chem 275(18): 13621-13627.

Kooijman EE, Chupin V, de Kruijff B, Burger KN (2003) Modulation of membrane curvature by phosphatidic acid and lysophosphatidic acid. Traffic 4(3): 162-174.

Lavieri R, Scott SA, Lewis JA, Selvy PE, Armstrong MD, Alex Brown H, Lindsley CW (2009) Design and synthesis of isoform-selective phospholipase D (PLD) inhibitors. Part II. Identification of the 1,3,8triazaspiro[4,5]decan-4-one privileged structure that engenders PLD2 selectivity. Bioorg Med Chem Lett 19(8): 2240-2243.

Lavieri RR, Scott SA, Selvy PE, Kim K, Jadhav S, Morrison RD, Daniels JS, Brown HA, Lindsley CW (2010) Design, synthesis, and biological evaluation of halogenated N-(2-(4-oxo-1-phenyl-1,3,8triazaspiro[4.5]decan-8-yl)ethyl)benzamides: discovery of an isoformselective small molecule phospholipase D2 inhibitor. J Med Chem 53(18): 6706-6719.

Lemmon MA, Schlessinger J (2010) Cell signaling by receptor tyrosine kinases. Cell 141(7): 1117-1134.

Lewis JA, Scott SA, Lavieri R, Buck JR, Selvy PE, Stoops SL, Armstrong MD, Brown HA, Lindsley CW (2009) Design and synthesis of isoform-selective phospholipase D (PLD) inhibitors. Part I: Impact of alternative halogenated privileged structures for PLD1 specificity. Bioorg Med Chem Lett 19(7): 1916-1920.

Lindsley CW, Brown HA (2012) Phospholipase D as a therapeutic target in brain disorders. Neuropsychopharmacology 37(1): 301-302.

Liu Y, Kach A, Ziegler U, Ong AC, Wallace DP, Arcaro A, Serra AL (2013) The role of phospholipase D in modulating the MTOR signaling pathway in polycystic kidney disease. PloS ONE 8(8): e73173.

Loonen AJM, Soudijn W (1985) Halopemide, a new psychotropic agent. Pharm Weekbl 7(1): 1-9.

Lucocq J, Manifava M, Bi K, Roth MG, Ktistakis NT (2001) Immunolocalisation of phospholipase D1 on tubular vesicular membranes of endocytic and secretory origin. Eur J Cell Biol 80(8): 508-520.
Martelli AM, Evangelisti C, Nyakern M, Manzoli FA (2006) Nuclear protein kinase C. Biochim Biophys Acta 1761(5-6): 542-551.

Martelli AM, Fala F, Faenza I, Billi AM, Cappellini A, Manzoli L, Cocco L (2004) Metabolism and signaling activities of nuclear lipids. Cell Mol Life Sci 61(10): 1143-1156.

Mathews TP, Hill S, Rose KL, Ivanova PT, Lindsley CW, Brown HA (2015) Human phospholipase D activity transiently regulates pyrimidine biosynthesis in malignant gliomas. ACS Chem Biol 10(5): 1258-1268.

Min J, Zaslavsky A, Fedele G, McLaughlin SK, Reczek EE, De Raedt T, Guney I, Strochlic DE, Macconaill LE, Beroukhim R, Bronson RT, Ryeom S, Hahn WC, Loda M, Cichowski K (2010) An oncogene-tumor suppressor cascade drives metastatic prostate cancer by coordinately activating Ras and nuclear factor-kappaB. Nat Med 16(3): 286-294.

Mlecnik B, Bindea G, Kirilovsky A, Angell HK, Obenauf AC, Tosolini M, Church SE, Maby P, Vasaturo A, Angelova M, Fredriksen T, Mauger S, Waldner M, Berger A, Speicher MR, Pages F, Valge-Archer V, Galon J (2016) The tumor microenvironment and Immunoscore are critical determinants of dissemination to distant metastasis. Sci Transl Med 8(327): $327 \mathrm{ra} 26$.

Monovich L, Mugrage B, Quadros E, Toscano K, Tommasi R, LaVoie S, Liu E, Du Z, LaSala D, Boyar W, Steed P (2007) Optimization of halopemide for phospholipase D2 inhibition. Bioorg Med Chem Lett 17(8): 2310-2311.

Noh D-Y, Ahn S-J, Lee R-A, Park I-A, Kim J-H, Suh P-G, Ryu S-H, Lee K-H, Han J-S (2000) Overexpression of phospholipase D1 in human breast cancer tissues. Cancer Lett 161(2): 207-214.

Rane JK, Greener S, Frame FM, Mann VM, Simms MS, Collins AT, Berney DM, Maitland NJ (2016) Telomerase activity and telomere length in human benign prostatic hyperplasia stem-like cells and their progeny implies the existence of distinct basal and luminal cell lineages. Eur Urol 69(4): 551-554.

Roehrborn CG (2008) Pathology of benign prostatic hyperplasia. Int J Impot Res 20(Suppl 3): S11-S18.

Rumsby M, Schmitt J, Sharrard M, Rodrigues G, Stower M, Maitland N (2011) Human prostate cell lines from normal and tumourigenic epithelia differ in the pattern and control of choline lipid headgroups released into the medium on stimulation of protein kinase C. Br J Cancer 104(4): 673-684.

Saito M, Iwadate M, Higashimoto M, Ono K, Takebayashi Y, Takenoshita S (2007) Expression of phospholipase D2 in human colorectal carcinoma. Oncol Rep 18(5): 1329-1334.

Schauer IG, Rowley DR (2011) The functional role of reactive stroma in benign prostatic hyperplasia. Differentiation 82(4-5): 200-210.

Schmitt J, Noble A, Otsuka M, Berry P, Maitland NJ, Rumsby MG (2014) Phorbol ester stimulates ethanolamine release from the metastatic basal prostate cancer cell line PC3 but not from prostate epithelial cell lines LNCaP and P4E6. Br J Cancer 111(8): 1646-1656.

Scott SA, Selvy PE, Buck JR, Cho HP, Criswell TL, Thomas AL, Armstrong MD, Arteaga CL, Lindsley CW, Brown HA (2009) Design of isoformselective phospholipase D inhibitors that modulate cancer cell invasiveness. Nat Chem Biol 5(2): 108-117.

Sun Y, Niu J, Huang J (2009) Neuroendocrine differentiation in prostate cancer. Am J Transl Res 1(2): 148-162.

Terry S, Beltran H (2014) The many faces of neuroendocrine differentiation in prostate cancer progression. Front Oncol 4: 60.

Tu-Sekine B, Raben DM (2004) Nuclear production and metabolism of diacylglycerol. Eur J Histochem 48(1): 77-82.

Uchida N, Okamura S, Kuwano H (1999) Phospholipase D activity in human gastric carcinoma. Anticancer Res 19(1B): 671-675.

Uchida N, Okamura S, Nagamachi Y, Yamashita S (1997) Increased phospholipase D activity in human breast cancer. J Cancer Res Clin Oncol 123(5): 280-285.

Ulukaya E, Frame FM, Cevatemre B, Pellacani D, Walker H, Mann VM, Simms MS, Stower MJ, Yilmaz VT, Maitland NJ (2013) Differential cytotoxic activity of a novel palladium-based compound on prostate cell lines, primary prostate epithelial cells and prostate stem cells. PloS ONE 8(5): e64278.

Ushio-Fukai M (2006) Nuclear phospholipase D1 in vascular smooth muscle.

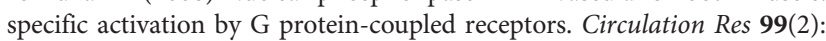
$116-118$.

Vitale N, Caumont AS, Chasserot-Golaz S, Du G (2001) Phospholipase D1: a key factor for the exocytotic machinery in neuroendocrine cells. EMBO J 20(10): 2424-2434. 
Wang X, Devaiah SP, Zhang W, Welti R (2006) Signaling functions of phosphatidic acid. Prog Lipid Res 45(3): 250-278.

Winter JN, Fox TE, Kester M, Jefferson LS, Kimball SR (2010) Phosphatidic acid mediates activation of mTORC1 through the ERK signaling pathway. Am J Physiol Cell Physiol 299(2): C335-C344.

Yang J-S, Gad H, Lee SY, Mironov A, Zhang L, Beznoussenko GV, Valente C, Turacchio G, Bonsra AN, Du G, Baldanzi G, Graziani A, Bourgoin S, Frohman MA, Luini A, Hsu VW (2008) A role for phosphatidic acid in COPI vesicle fission yields insights into Golgi maintenance. Nat Cell Biol 10(10): 1146-1153.

Yokoyama NN, Shao S, Hoang BH, Mercola D, Zi X (2014) Wnt signaling in castration-resistant prostate cancer: implications for therapy. Am J Clin Exp Urol 2(1): 27-44.

Yoon MS, Sun Y, Arauz E, Jiang Y, Chen J (2011) Phosphatidic acid activates mammalian target of rapamycin complex 1 (mTORC1) kinase by displacing FK506 binding protein 38 (FKBP38) and exerting an allosteric effect. J Biol Chem 286(34): 29568-29574.

Zhao Y, Ehara H, Akao Y, Shamoto M, Nakagawa Y, Banno Y, Deguchi T, Ohishi N, Yagi K, Nozawa Y (2000) Increased activity and intranuclear expression of phospholipase D2 in human renal cancer. Biochem Biophys Res Commun 278(1): 140-143.

Zhou H, Huang S (2011) Role of mTOR signaling in tumor cell motility, invasion and metastasis. Curr Protein Pept Sci 12(1): 30-42.

This work is published under the standard license to publish agreement. After 12 months the work will become freely available and the license terms will switch to a Creative Commons AttributionNonCommercial-Share Alike 4.0 Unported License. 